\title{
“AKTIVASI" MAKNA-MAKNA TEKS DENGAN PENDEKATAN KONTEMPORER: Epistemologi Hermeneutika Subjektif-Fiqhiyyah El-Fadl
}

\author{
Khabibi Muhammad Luthfi \\ Institut Pesantren Mathaliul Falah (IPMAFA) Pati \\ e-mail: habibi.abeb@gmail.com
}

\begin{abstract}
This paper aims to review the use of hermeneutics Khaled M. Abou ElFadl in finding a potential meaning of the text Quran and the hadith in terms of epistemology. It departs from El-Fadl is one of the contemporary Muslim intellectuals who has criticized the authoritarianism of most Muslims to be removed because against God and just believe in the single meanings. Though the text made by God to contain the potential meanings can be harmonized and contextualize the demands of the times. In addition, hermeneutic departing from the study of Islamic law or fiqh, which is often confused with the Quranic text or as fiqh is the text itself. With a philosophical approach based on literature data and discourse analysis found that El-Fadl offers hermeneutics subjective-fiqhiyyah based on the interaction between the text and the interpretive community and "a little concerned" about the role of the author or the Lord so as to present a reinterpretation of the text in the form of the potential meaning of the text which at the same time avoiding the imposition of the single meaning that generally do lending institutions fatwa. Besides that distinguishes it from other contemporary hermeneutics Muslim intellectuals or philosophers west are El-Fadl did not recognize the individual's ability to interpret text, but "community" or in the language of jurisprudence called mujtahid jam'i and was able to explain the position of God in the stage of interpreting the text without having to remove it as subjective hermeneutics of the West.
\end{abstract}

\begin{abstract}
Abstrak: Tulisan ini bertujuan mengulas hermeneutika yang digunakan Khaled M. Abou El-Fadl dalam menemukan potensi-potensi makna dalam teks Alquran dan hadis ditinjau dari epistemologi. Ini berangkat dari El-Fadl merupakan salah satu intelektual muslim kontemporer yang kritis atas otoritarianisme sebagian umat muslim harus dihilangkan karena melawan Tuhan dan hanya percaya terhadap pemaknaan tunggal. Padahal teks yang dibuat oleh Tuhan mengandung potensi-potensi makna yang bisa diselaraskan dan dikontekstualisasikan dengan tuntutan zaman. Selain itu hermeneutikanya berangkat dari kajian hukum Islam atau fikih yang sering tertukar dengan teks Alquran atau seolah fikih adalah teks itu sendiri. Dengan pendekatan filosofis berbasis data pustaka dan analisis wacana, ditemukan bahwa El-Fadl menawarkan hermeneutika subjektiffiqhiyyah yang berbasis pada interaksi antara teks dan komunitas interpretasi dan "sedikit peduli" terhadap peran pengarang atau Tuhan sehingga mampu menghadirkan pemaknaan ulang terhadap teks berupa potensi-potensi makna teks yang sekaligus menghindari pemaksaan terhadap pemaknaan tunggal yang
\end{abstract}


umumnya dilakukan lembaga pemberi fatwa. Selain itu yang membedakannya dengan hermeneutika intelektual muslim kontemporer lain atau filosuf Barat adalah El-Fadl tidak mengakui kemampuan individu dalam menafsirkan teks, melainkan "komunitas" atau dalam bahasa fikih disebut mujtahid jamî dan mampu menjelaskan posisi Tuhan dalam tahapan menafsirkan teks tanpa harus menghilangkannya sebagaimana hermeneutika subjektif dari Barat.

Keywords: hermeneutics; text; author; community-interpretation; authoritarianism

\section{A. Pendahuluan}

Di era kontemporer, discoursuse kajian teks (baca: al-Qur'an atau Hadis) dengan meminjam metodologi ilmu-ilmu sosial humaniora Barat, terutama hermeneutik merupakan hal yang tidak asing. Berbagai referensi atau penelitian ilmiah baik berbahasa Asing, Arab atau Inggris maupun bahasa Indonesia yang mengaplikasikan atau sekedar mewacanakan hermeneutik menghiasi hampir di seluruh perpustakaan Perguruan Tinggi Keagamaan Islam (PTKI), bahkan dunia keislaman secara global. Ini berberbeda dengan era sebelumnya (modern), khususnya di Indonesia yang anti terhadap hermeneutik ${ }^{1}$ Namun demikian kajian teks dengan menggunakan pendekatan hermeneutik yang spesifik terhadap hukum Islam dirasa tidak sesemarak kajian teks pada umumnya. ${ }^{2}$ Bisa jadi, ini dikarenakan fikih atau lebih luasnya hukum Islam sudah dianggap masuk sebagai bagian kajian teks secara umum itu (penafsiran al-Qur'an dan hadis). Lebih jauh, seperti diketahui, popularitas mazhab fikih seperti Imam Syafi'i (819 M) lebih terkenal dibanding mazhab teologi dan sufi. Ini juga dibuktikan dengan hukum Islam (fikih) seperti diungkapkan Schacht (1969) merupakan elemen terpenting dalam praktik kehidupan mayoritas umat Islam. ${ }^{3}$

1Penolakan ini disinyalir adanya kekhawatiran umat muslim terhadap sakralitas al-Qur'an yang ternodai dengan istilah hermeneutik. Ditilik secara historis, hermeneutik dianggap sebagai metode penafsiran untuk kitab Bible yang di dalamnya penuh teka-teki (baca: pemalsuan) dan profan karena disusun manusia biasa. Selain itu di Islam telah memiliki metode sendiri yang disebut tafsir atau ta'wīl yang sudah terujui oleh zaman. Lihat, Machasin, "Sumbangan Hermeneutik terhadap Ilmu Tafsir" Gerbang: Jurnal Studi Agama dan Demokrasi, Vol. 14. No. V, Surabaya: eLSAD. 2003, h. 122.

2Pemikir Islam kontemporer lain yang juga berpijak dari Hukum Islam adalah Jasser Audah (2008). Dengan pendekatan sistem Audah ingin "merevitalisasi" hukum islam khususnya uSūl alFiqhnya Syatibī tentang maqāsid asy-Syarīah. Lihat, Jasser Auda, Maqasid al-Shariah as Philosophy of Islamic Law: A System Approach (London: The International Institute of Islamic Thought, 2007), h. 29-33.

3Joseph Schacht, "Theology and Law in Islam," dalam G.E. von Grunebaum (ed.), Theology and Law in Islam, (Weisbaden: Otto Harrasowitz, 1969), h. 23. 
Seluruh praktik ubudiyyah maupun muamalah umat Muslim selalu diukur dari fikih sehingga seolah-olah al-Qur'an-yang seharusnya merupakan sumberadalah fikih itu sendiri.

Berangkat dari kajian hukum Islam yang dipersepsikan sebagai al-Qur'an inilah Khaled Abou El-Fadl (El-Fadl) melalui pendekatan hermeneutika mencoba meluruskan. Menurutnya, fikih yang ada pada saat ini merupakan beberapa makna yang dihasilkan dari ribuan-bahkan tak terbatas-makna al-Qur'an. Jika ada yang menganggap makna ini final, dan memaksa orang lain untuk mengikuti dan mempraktekkan makna itu sebagaimana lembaga fatwa mazhab, bahth al-masāill, komisi fatwa MUI (Majelis Ulama Indonesia), Majlis Tarjih- dalam tradisi hukum Islam berarti ia "ingin menjadi Tuhan". ${ }^{4}$ Karena menurutnya, karya Tuhan yang berupa al-Qur'an itu dilahirkan tidak hanya untuk satu makna, misalnya untuk orang Arab saja, melainkan untuk seluruh umat manusia yang memiliki latar belakang berbeda sehingga bisa menemukan makna yang berbeda pula. Dengan demikian, Tuhan tidak bisa diwakili hanya dengan satu makna saja dan al-Qur'an pada dasarnya memiliki potensi maknamakna tersembunyi yang butuh "diaktivasi" (dihidupkan atau dimunculkan) dengan hermeneutika agar șālih li kull zamān wa makān\} (sesuai semua waktu dan keadaan). Atas dasar ini tulisan ini hendak membahas hermeneutika ElFadl, terutama pada model hermeneutika yang dipakai dan landasan epistemologinya, kontekstualisasinya dalam hukum islam serta beberapa diferensiasi dan kritik terhadapnya.

\section{B. Sekilas Biografi dan Intelektualitas El-Fadl}

Khaled Medhat Abou El-Fadl merupakan salah satu pemikir Islam kontemporer (kekinian) yang lahir pada 1963 di Kuwait. El-Fadl berasal dari keluarga yang concern dalam kajian hukum. Ayahnya adalah pengacara. Sejak kecil ElFadl diarahkan ayahnya agar mengikuti jejaknya, bahkan oleh Ayanhnya sejak masa kanak-kanak ditanya tentang masalah-masalah hukum. Maka tak heran, kelak El-Fadl menjadi pakar dalam bidang hukum Islam.

El-Fadl kecil langsung dididik orang tunya. Selain digembleg tentang pendidikan hukum, oleh ayahnya layaknya anak kecil di Kuwait, El-Fadl juga diajar105.

${ }^{4}$ Khaled M. Abou el Fadel, Melawan Tentara Tuhan (Jakarat: Serambil Ilmu Semesta, 2003), h. 
kan ilmu-ilmu keislaman secara mendalam, bahkan pada umur 12 tahun sudah hafal al-Qur'an. Bersamaan itu El-Fadl juga belajar di pendidikan dasar. Setelah itu (1975) El-Fadl Hijrah ke Mesir untuk melanjutkan pendidikan pendidikan menengah dan atas. Di sinilah ia berkenalan dengan Syaikh Muhammad alGhazālì (w. 1995), tokoh pemikir Islam moderat dari barisan revivalis yang sangat dikaguminya. ${ }^{5}$

Pada tahun 1982, El-Fadl pergi kuliah ke Yale University, Amerika. Pada tahun 1986, El-Fadl lulus studi bachelor-nya dengan predikat cumlaude dalam kajian ilmu hukum. Tiga tahun kemudian (1989) El-Fadl menyelesaikan studi Magister Hukum pada University of Pennsylvania. Setelah itu El-Fadl menjadi staf pengajar di University of Texas di Austin sekaligus sebagai pengacara bidang hukum dagang dan hukum imigrasi di Pengadilan Tinggi (Suppreme Court Justice) wilayah Arizona. Program doktoral diselesaikan El-Fadl pada tahun 1999 di di University of Princeton dengan bergelar Ph.D. dalam bidang hukum Islam. Hingga akhirnya El-Fadl dianugerahi guru besar dalam hukum Islam dari School of Law, University of California, Los Angeles (UCLA).

Selama kuliah hingga menjadi profesor inilah ia banyak bergelut dengan karya-karya para filosof bahasa seperti Charles Sanders Peirce (1914), Heidegger (1976), Roland Barthes (1980), Gadamer (2002), Umberto Eco (2007), dan R.B Friedman (2012). Tokoh-tokoh ini kelak mempengaruhi pemikiran hermeneutiknya, meski tidak langsung. Selain tentunya, sebelumnya sudah bergelut dengan karya pemikir Islam baik klasik maupun kontemporer seperti Ibn Qayyim al-Jauzi (1350 M.) dan Fazlur Rahman (1988). El-Fadl termasuk intelektual yang produktif dalam bidang hukum Islam. Di antara karya-karyanya dalam bentuk buku adalah The Authoritative and Authoritarian in Islamic Discourses (Dar Taiba, 1997), Rebellion and Violence in Islamic Law (Cambridge University Press, 2001), Conference of the Books: The Search for Beauty in Islam (University Press of America/Rowman and Littlefield, 2001), Speaking in God's Name: Islamic law, Authority and Women (Oneworld Press, Oxford, 2001), And God Knows the Soldiers: The Authoritative and Authoritarian in Islamic Discourses (UPA/Rowman and Littlefield, 2001), The Place of Tolerance in Islam (Beacon Press, 2002), Islam and the Challenge of Democracy (Princeton University Press, 2004), The Great Theft: Wrestling Islam from the Extremists (Harper

5Zuhairi Misrawi, "Khaled Abou El-Fadl Melawan atas Nama Tuhan", dalam Perspektif Progresif, Edisi Perdana Juli-Agustus, 2005, h. 15. 
San Francisco, 2005), The Search for Beauty in Islam: Conference of the Books (Rowman \& Littlefield Publishers, Inc, 2006) dan Reasoning with God: Reclaiming Shari'ah in the Modern Age (Rowman \& Littlefield Publishers, Inc, Oktober 2014).

Karya-karya El-Fadl baik buku maupun artikel dalam jurnal ilmiah hampir semua berbahasa Inggris, meski demikian ia sebenarnya -minimal- menguasai tiga bahasa, yaitu Inggris, Arab dan Persia. Beberapa karyanya sudah diterjemahkan ke dalam bahasa Indonesia, termasuk karya monumentalnya Speaking in God's Name: Islamic Law, Authority and Woman diterbitkan Oneworld Publication tahun 2003 yang diterjemahkan "Atas Nama Tuhan dari fikih Otoriter ke Fikih Otoritatif' dan diterbitkan Penerbit Serambi Yogyakarta (2004).

Terlepas dari popularitas dan intelektualitas, El-Fadl pada awalnya merupakan penganut paham Wahabi yang sangat ektrim, hingga berubah seratus delapan puluh derajat menjadi pengkritik paham itu. Mungkin, ini merupakan keuntungan yang secara psikologis-sosiologis pernah berada dalam posisi penebar otoritarianisme, sehingga menjadi salah satu motivasi dalam karyakaryanya yang sangat kritis. ${ }^{6}$

\section{Otoritarianisme: Mencari Pemegang Otoritas Tuhan}

El-Fadl dalam karya-karyanya sebenarnya tidak secara eksplisit mengkonsep hermeneutik layaknya filusuf bahasa dan lebih banyak mempraktekkannya. Hermeneutik yang ada atau dinisbatkan padanya lebih pada konseptualisasi dan konstruksi yang ada pada pemikirannya, terutama dalam bukunya Speaking in God's Name: Islamic Law, Authority and Woman. El-Fadl berkata:

"Saya tidak akan menyusun definisi tentang hermeneutika. Bahkan saya tidak yakin bisa mendefinisikannya. Saya pikir kita dapat menggambarkan sebuah hermeneutika sebagai kajian yang melibatkan pemahaman terhadap kaidah-kaidah ilmu tafsir dan epistemologi pemahaman." ${ }^{7}$

Bisa jadi ini dikarenakan bidang disiplin ilmunya adalah Hukum Islam yang cenderung bersifat positivistik dibanding filosofis. Namun demikian, dalam

\footnotetext{
6Yusriandi, "Hermeneutika Hadis Abou El-Fadl," dalam Sahiron Syamsuddin (ed), Hermeneutika Al-Qur'an dan Hadis (Yogyakarta: elSAQ Press, 2010), h. 413.

${ }^{7}$ Khaled M. Abou el Fadel, Speaking in God's Name: Islamic Law, Authority and Woman (Oxoford: Oneworld Publications, 2003), h. 118.
} 
literatur-literatur yang mengkajinya, El-Fadl diidentikkan sebagai tokoh yang mencetuskan model hermeneutik tersendiri. Ini dikarenakan dalam kajian buku itu, El-Fadl dengan fasih membahas teori tokoh hermeneutik dan segitiga hermeneutik, yaitu pengarang (author), pembaca (reader) dan teks sebagai penghubung antara keduanya. ${ }^{8}$

Berdasarkan buku itu kegelisahan El-Fadl diilhami adanya otoritarianisme yang dilakukan oleh para pembaca-dalam konteks ini ahli hukum Islam CRLO (Council for Scientific Research And legal Opinions atau lembaga lembaga resmi di Arab Saudi yang bertugas memberikan fatwa) ${ }^{9}$ terhadap teks-teks al-Qur'an dan hadis. Otoritarianisme di sini adalah lembaga tersebut merasa sebagai "wakil tuhan" dalam memaknai teks suci, terutama yang terkait pada ketidakadilan gender. Dalam pemaknaan (baca: fatwa) lembaga ini menempatkan posisi perempuan layaknya "budak" para laki-laki. Dalam masalah ini El-Fadl melihat, hanya ada satu yang berhak membaca dan memaknai teks, yaitu CLRO. Lembaga lain atau orang lain tidak diberi hak membaca dengan pemaknaan lain terhadap teks. Atas dasar inilah, El-Fadl ingin menyelaraskan hubungan antar tiga segitiga hermeneutika dalam pergumulan pemikiran hukum Islam pada khususnya dan pemikiran pada umumnya.

Sebelum mengutarakan relasi segitiga hermeneutika itu, El-Fadl ingin menyelesaikan terlebih dahulu konsep otoritas karena inilah pintu masuk dalam kontekstualisasi teks. Otoritas oleh El-Fadl dibedakan menjadi dua. Pertama, otoritas koersif yaitu kemampuan untuk mengarahkan perilaku orang lain dengan cara membujuk, mengambil keuntungan, mengancam, atau menghukum, sehingga orang yang berakal sehat akan berkesimpulan bahwa untuk tujuan praktis mereka tidak punya pilihan lain kecuali harus menurutinya. Kedua, otoritas persuasif yaitu kemampuan untuk mengarahkan keyakinan atau perilaku seseorang atas dasar kepercayaan. ${ }^{10}$ Dengan meminjam konsep

${ }^{8}$ Orang yang melakukan inetrpretasi harus mengenal pesan atau kecondongan sebuah teks, lalu harus meresapi isi teks sehingga pada mulanya "yang lain" kini menjadi "aku" penafsir itu sendiri. Bertolak dari asumsi di atas, dapat dikatakan bahwa hermeneutika merupakan system of rules of interpretation. E. Sumaryono, Hermeneutik: Sebuah Metode Filsafat (Yogyakarta: Kanisius, 1999), h. 31.

${ }^{9}$ Amin Abdullah, "Pendekatan Hermeneutik dalam Studi Fatwa-fatwa Keagamaan" dalam pengantar buku Khaled Khaled M. Abou el Fadel, Atas Nama Tuhan: dari Fiqih Otoriter ke Fiqih Otoritatif, terj. Cecep Lukman Yasin, (Jakarta: PT Serambi Ilmu Semesta, 2004), h. ix.

${ }^{10}$ Khaled M. Abou el Fadel, Speaking in God's Name, h. 18. 
Richard Friedman, El-Fadl memperjelas otoritas koesif sebagai "memangku otoritas" (being in authority; berada di dalam kekuasaan) yaitu suatu otoritas yang didapatkan dengan jabatan struktural dan cenderung memaksa kepada orang lain untuk menerima otoritas tersebut. Sementara yang kedua sejajar dengan "memegang otoritas" (being anauthority; keberadaan kekuasaan yaitu suatu otoritas yang didapatkan karena kapabilitas dan akseptabilitas keilmuan seseorang sehingga memunculkan kesadaran orang lain untuk menerimanya atau mengikutinya. ${ }^{11}$ El-Fadl juga memberikan catatan bahwa relasi otoritas, baik yang persuasif maupun koersif bersandar pada seperangkat representasi yang termanifestasikan dalam sejumlah klaim, seperti klaim tentang kekuasaan, wewenang dan pengetahuan. ${ }^{12}$

Dalam konteks keislaman (baca: hukum islam), menurut El-Fadl kedua otoritas ini bisa digunakan, hanya saja harus memenuhi tiga syarat yang harus dimiliki pemegang otoritas. Pertama, kompetensi adalah proses pembuktian sejarah dan pengujian autentisitas dari perintah Tuhan atau Nabi agar dapat diketahui bahwa perintah tersebut benar-benar berasal dari Allah atau Nabi. ${ }^{13}$ Dalam hal ini al-Qur'an dan hadis merupakan kompetensi terahir yang tidak bisa gugat. Di sini El-Fadl tidak berspekulasi membuka perdebatan tentang otenstitas sejarah al-Qur'an dan hadis, karena yang relevan baginya adalah "penentuan maknanya" (to determine its meaning). Kedua, penetapan makna, artinya tindakan untuk menentukan makna sebuah teks. Selama perintah-perintah Tuhan bersandar pada sebuah teks, maka perintah-perintah teks tersebut bersandar pada sebuah bahasa. ${ }^{14}$ Dalam konteks inilah El-Fadl mewajibkan adanya proses interaksi antara pengarang, pembaca dan teks dengan cara negosiasi. Ini dikarenakan bahasa memiliki potensi-potensi makna pada dirinya sendiri yang selalu berubah berdasarkan konteks, bahkan pembaca tidak mampu mengontrolnya.

Ketiga, perwakilan yaitu manusia yang memiliki kewenangan menjadi wakil tuhan di bumi. Dalam prakteknya, menurut El-Fadl beberapa wakil Tuhan (orang-orang Islam yang beriman dan saleh disebut dengan wakil umum) akan

\footnotetext{
11 Ibid, h. 18-19.

${ }^{12}$ Khaled M. Abou el Fadel, Melawan Tentara Tuhan, h. 105.

${ }^{13}$ Khaled M. Abou el Fadel, Speaking in God's Name, h. 25.

${ }^{14}$ Ibid., h. 89.
} 
menundukkan keinginannya dan menyerahkan sebagian keputusannya kepada sekelompok orang atau wakil dari golongan tertentu (yaitu para ahli hukum). Ini dilakukan karena wakil dari golongan tersebut dianggap memiliki otoritas. Dengan begitu kelompok khusus ini menjadi otoritatif karena dipandang memiliki kompetensi dan pemahaman khusus terhadap perintah Tuhan.15

Namun demikian, El-Fadl mensyaratkan lima landasan bagi golongan tertentu tersebut, yaitu 1) kejujuran yang menunjukkan bahwa sikap tidak berpura-pura dalam memahami apa yang sebenarnya tidak diketahui dan bersikap terus terang terhadap ilmu dan kemampuannya, 2) kesungguhan yakni secara logis wakil kelompok tertentu ini telah mengerahkan segenap upaya rasional dalam menemukan dan memahami serangkaian persoalan tertentu, 3) menyeluruhan yang berarti usaha dalam menyelidiki semua maksud Tuhan dan mengakaitkannya dengan perintah lain yang relevan, 4) rasionalitas yakni menganalisa dan memahami maksud Tuhan dengan cara rasional dan 5) pengendalian diri yakni kerendahan hati dan pengendalian diri yang layak dalam menjelaskan maksud Tuhan. Kelima landasan ini menjelaskan hubungan keberwenangan yang dilandasi saling percaya -dengan ilustrasi- bahwa $Y$ akan memandang X memiliki otroitas untuk diikuti karena Y percaya pada Y secara rasional. ${ }^{16}$

Dengan demikian, yang memiliki otoritas dalam pembacan teks sekaligus kontekstualisasinya yang diberlakukan untuk umat secara umum dalam kajian keislaman menurut El-Fadl adalah para ahli hukum. Hanya saja, catatannya, kelima landasan tersebut harus selalu melekat, manakala tidak ada -meskipun hanya satu- akan memunculkan, dalam bahasa El-Fadl otoritarianisme, terutama dalam wilayah kontekstualisasi atau praktek dari makna yang dihasilkan dari teks. Selain itu, otoritarianisme sebenarnya juga terletak pada usaha membatasi, bahkan menutup kemungkinan makna lain yang dikehendaki Tuhan dalam teks dan dalam proses penyampaian makna hasil dari penafsiran tersebut, umat Muslim dipaksa untuk mengikutinya tanpa memberi peluang melihat makna lain. Ini sebagaimana telihat dari pernyataan El-Fadl:

"Otoritarianisme adalah tindakan "mengunci" dan mengurung kehendak Tuhan atau kehendak teks, dalam sebuah penetapan tertentu, dan

${ }^{15}$ Ibid., h. 53.

16Ibid,., h. 54-57. 
kemudian menyajikan penetapan tersebut sebagi sesuatu yang pasti, absolut, dan menentukan ... Otoritarianisme merupakan tindakan yang melampaui otoritas atau kekuasaan yang dimandatkan sedemikian rupa sehingga menyelewengkan atau mengambil alih kekuasaan dari pemberi mandat. Sulit dibayankan bagaimana seseorang dapat melakukan hal semacam itu tanpa melanggar setidaknya salah satu prasyarat keberwenangan tersebut."17

Selain menawarkan lima syarat di atas, Khalid menawarkan praduga epistemologis (epistemological presupposition) yang dipinjam dari Friedman guna meminimalisir otoritarianisme. Menurutnya, praduga epistemologi ini adalah upaya berbagi kerangka epistemologi antara pemegang otoritas dan orang yang mengikutinya atau adanya titik temu pemahaman bersama mengenai kepatuhan terhadap superioritas pengetahuan (pemegang) dan pemahaman orang lain (pemangku otoritas) yang mengandaikan bahwa pengetahuan dan pemahaman makna teks pada dasarnya bisa dimiliki oleh siapapun. Jadi di antara keduanya harus berbagi kerangka epistemologis yang sama untuk menentukan hal-hal apa saja yang dapat diketahui rasio dan pengalaman manusia meskipun bagi orang yang patuh, sulit untuk mendapatkan pengetahuan atau pengalaman tersebut karena bisa jadi belum memiliki pengetahuan, kebijaksanaan dan kesempatan yang dibutuhkan.18 Dengan begitu pluralitas makna juga terbuka bagi otoritas-otoritas lain tanpa saling memaksa. Berikut gambar perbedaan hermeneutika dan hermeneutika otoritarianisme.

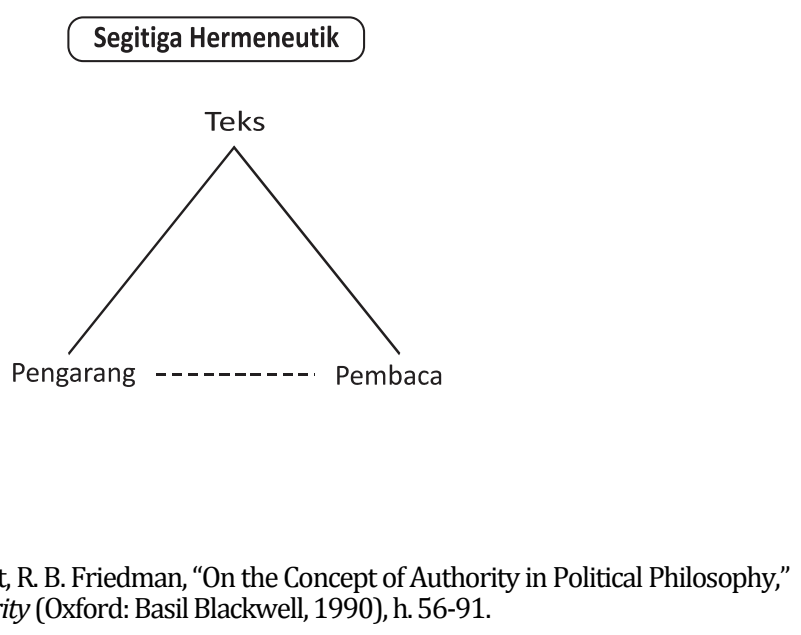

${ }^{17} \mathrm{Ibid}$, h. 93.

${ }^{18}$ Penjelasan lebih lanjut, R. B. Friedman, "On the Concept of Authority in Political Philosophy," dalam Joseph Raz (ed.), Authority (Oxford: Basil Blackwell, 1990), h. 56-91. 


\section{Hermeneutik Otoritarianisme}

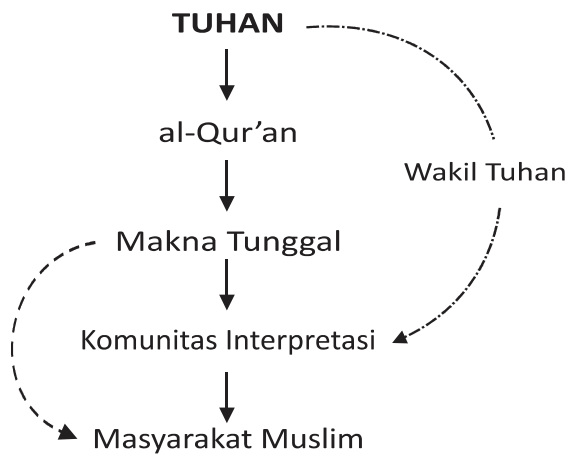

Keterangan:

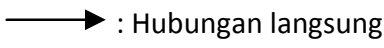

-...... : Hubungan tidak langsung

: Potensi makna lain

\section{Gambar 1.}

Perbedaan Hermeneutika dan Hermeneutika Otoritarianisme

\section{Hubungan Pengarang (Author), Komunitas Interpretasi (Reader) dan Teks Otonom yang Miliki Potensi Makna}

Sebagai intelektual Muslim, dalam menawarkan dan memproduksi maknamakna baru dari teks, El-Fadl sebenarnya membahas terlebih dahulu metodologi tafsir klasik baik dalam kajian ilmu tafsir maupun ușūl al-fiqh seperti asbāb al-nuzūl-wurūd, muțlaq-muqayyad dan haqīqì-majāzi. Hanya saja, El-Fadl kurang tertarik mengkajinya terlalu dalam, menurutnya makna yang dihasilkan metodologi ini hanya untuk menemukan makna pada waktu al-Qur'an dan hadis masih eksis (masa Nabi), sehingga kurang relevan dalam menemukan makna kekinian. Karena, tambah El-Fadl, yang dibutuhkan dalam konteks hukum Islam adalah makna kekinian. Penelitian hukum tidak terkosentrasi pada maksud asal teks untuk melayani teks melainkan untuk merespon realitas sosial-politik 
dengan menggunakan teks. ${ }^{19}$ Bahkan, metodologi klasik ini dianggap kurang berguna.

"Daripada sekedar melakukan penyeledikan panjang lebar terhadap kategori-ketegori dan kaidah-kaidah interpretasi tradisional, akan jauh lebih berguna jika kita melakukan pendekatan konseptual terhadap displin tersebut ... Daripada menggunakan label-label bahasa yang mungkin atau tidak mungkin memiliki makna tertentu pada masa modern ini, lebih baik kita menganalisis persoalan-persoalan epistemologis yang mengilhami munculnya label-label tersebut. Dalam inti analisis tersebut terdapat peran pengarang, teks dan pembaca dalam menetukan makna." 20

Ini bisa dimaklumi karena hermeneutika El-Fadl tidak langsung menggali makna-makna teks sebagaimana hermeneutika lain, melainkan analisis kritis mengenai praktik penafsiran hukum Islam dalam teks yang otoriter, seolah-olah menjadi satu-satunya "wakil Tuhan" dan menciderai integritas teks, sehingga yang harus dibenahi adalah cara padangan mengenai otoritas teks dan otoritarisme pembaca. Dari sini kemudian El-Fadl bermaksud memposisikan antara pengarang, teks dan pembaca secara proposional.

Dalam mengajukan relasi segitiga hermeneutika itu langkah awal yang ditempuhnya adalah menolak adanya tiga mazhab (teori) dalam penentuan makna teks, yaitu makna teks ditentukan pengarang, ditentukan teks itu sendiri dan ditentukan pembaca. Menurutnya ketiganya memiliki hubungan yang kompleks, interaktif, dinamis dan dialektis, sehingga tidak ada unsur yang memainkan peran utama atau sampingan. ${ }^{21}$

Sebelum membahas hubungan ketiganya, ada baiknya membatasi ketiganya dalam pengertian El-Fadl. Pertama, pengarang. Dalam pandangan ElFadl, Tuhan sebagai pengarang teks al-Qur'an memiliki peranan penting dalam menetukan makna, bahkan dalam Islam harus dimulai dan diakhiri dengan maksud Tuhan. ${ }^{22}$ Namun demikian, entitas tuhan yang tidak terjangkau oleh manusia, maka jalan lain untuk menemukan maksud Tuhan adalah dengan bantuan konteks dan latar belakang histori suatu teks. Dengan kedua unsur ini

\footnotetext{
${ }^{19}$ Khaled M. Abou el Fadel, Speaking in God's Name, h. 118-120.

${ }^{20}$ Ibid., h. 120.

21 Ibid., h. 122.

${ }^{22}$ Ibid., h. 125.
} 
akan ditemukan makna awal dari sebuah teks. Makna awal ini bukan berarti makna yang paling benar sehingga menutup makna lain, melainkan pertunjuk untuk memahami dinamika antara teks dan penerima pertamanya. Kedua unsur ini juga tidak bisa menunjukkan atau mewakili seluruh maksud Tuhan dalam teks.

Posisi Tuhan, lanjut El-Fadl, sebenarnya bersifat simbolis yang terkait dengan tingkatan emosi yang lahir dari ingatan-ingatan yang telah lama dikenal. Ini sebagaimana terpahami dari maksud syariah adalah mencari jalan Tuhan, yang menuntut bahwa kehidupan yang baik harus dijalani dengan mengikuti ketentuan Tuhan. Dengan begitu teks selalu berbicara hukum (ketentuan) Allah, sebagai ketentuan yang menentukan dan mengikat segala keadaan, ${ }^{23}$ termasuk pemaknaan teks harus selalu dikaitkan denganNya.

Kedua, teks. Bagi El-Fadl sebuah teks memiliki potensi makna yang ada pada dirinya yang selalu berkembang dan berubah. Dengan meminjam konsep Umberto Eco, El-Fadl menyatakan bahwa teks merupakan karya yang terus berubah, sehingga terbuka bagi berbagai strategi pemaknaan. Artinya, teks akan selalu bisa menampung gerak pemaknaan yang dinamis. Dengan kata lain makna-makna ini akan selalu berubah mengikuti historisitas suatu teks. Baginya teks juga memiliki posisi sentral dalam penelitian atau pencariaan makna. Dengan begitu teks akan selalu terbuka untuk memunculkan potensi-potensi maknanya. Maka dalam hal ini, makna teks tidak boleh "disegel" oleh siapapun dengan hanya satu makna. Jika itu dilakukan, tambahnya, merupakan kesombongan intelektual. ${ }^{24}$ Ini menunjukkan bahwa teks pada dasarnya bersifat otonom, makna-makna yang bersemayam pada dirinya ada sebelum dibaca, tinggal bagaimana pembaca itu mampu menangkap atau memunculkan makna itu dalam teks.

Ketiga, pembaca. Berbeda dengan konsep pembaca di hermeneutika umumnya, pembaca yang dimasud El-Fadl bukanlah indvidu sebagaimana dalam tradisi filsafat Barat, melainkan suatu komunitas interpretasi yang memiliki lima syarat sebagaimana dijelaskan sebelumnya (wakil golongan tertentu). Komunitas ini digambarkan oleh El-Fadl dengan asumsi dasar para

${ }^{23}$ Ibid., h. 125.

${ }^{24}$ Ibid., h. 145-146. 
anggotanya memililiki epistemologi, persoalan dan nilai dasar yang sama dalam menghadapi objek kajian hukum islam. ${ }^{25}$ El-Fadl mencontohkan, kelompok interpretasi ini juga bisa dari yang terkecil, misal CLRO dan MUI, hingga dalam bentuk mazhab seperti Syafii, Sunni dan Syiah. Bahkan, menurutnya ini bisa dibuat skala yang lebih luas misal komunitas pemikiran hukum Islam, pemikiran filsafat islam dan lainnya, yang terpenting adalah meminjam istilah Rudolph hubungan awal dengan pokok bahasan ${ }^{26}$ atau sesuai dengan asumsi dasar seperti sebelumnya (para anggotanya).

Dengan mengacu pada masing-masing konsep segitiga di atas, akan tampak hubungan ketiganya. Teks bagi El-Fadl merupakan penghubung antara pengarang dan pembaca. Ini dikarenakan dalam konteks kekinian (kontemporer), terutama pasca kenabian, pembaca tidak akan pernah bertemu pengarang. Dengan demikian teks memilki peran sentral. Namun yang perlu dicatat, dalam pandangan El-Fadl, teks juga memiliki otonomi sendiri. Artinya, ketika teks sudah selesai difirmankan Tuhan, akan kembali pada sisi alamiahnya, yaitu mempunyai pluralitas pemaknaan. Kalaupun pada masa awal sudah ada pemaknaan yang dilakukan Nabi, ini bukan berarti menutup makna lain. Bahkan, menurutnya, teks juga memiliki integritas yang berkorelasi dengan dimensi ketuhanan dan komunitas interpretasi pada masa kini yakni teks memiliki daya hidup yang konsisten dan berkelanjutan.

"Jika Tuhan benar-benar berbicara untuk semua masa dan generasi, teks alQur'an tidak dapat dipahami sebatas konteks historisnya saja. Oleh karena itu, setelah menganalisis hubungan antara teks dan makna pada masa lalu (masa nabi), pertanyaannya menjadi, bagaimana seharusnya hubungan antara teks dan maknanya sekarang? Dengan ungkapan lain, jika teks ini ditulis pada saat ini akan seperti apa maknanya? Apakah ada alasan yang menuntut agar kita mengalihkan komunikasi dari masa lalu ke masa sekarang?"27

Pertanyaan-pertanyaan El-Fadl memberi isyarat bahwa menemukan makna awal teks berdasarkan historisnya itu penting. Historis ini digunakan untuk dijadikan salahsatu dasar untuk menolak atau menerima makna-makna

${ }^{25}$ Ibid., h. 122.

${ }^{26}$ Ibid., h. 123.

${ }^{27}$ Ibid., h. 126-127. 
(baru, yang) lain karena dinamika masa lalu merupakan hal mendasar bagi integritas teks (ungkapan) tertentu. El-Fadl mencotohkan ayat yang selalu memuji mereka yang "menjaga sesuatu di antara kedua pahanya" (al-hăfizīn li furüjihim). Pada masa sekarang bisa jadi akan muncul makna seperti selalu membersihkan alat vital atau tidak boleh $\mathrm{KB}$ atau memakai alat pelindung tambah untuk alat vital atau makna-makna lain, sementara berdasarkan dinamikan pada masa itu yang dimaksud adalah mastrubasi yang dipandang sebagai bentuk pelanggaran terhadap sesuatu yang berada di antara paha. Jika ada komunitas interpretasi yang pada hari ini memaknainya, "memakai alat pelindung tambah untuk alat vital" jelas ini bisa ditolak dengan alasan makna masa awalnya.

Setelah itu, yang lebih penting lagi bagi El-Fadl adalah menemukan makna kekinian dari teks karena meskipun memiliki potensi makna teks adalah "benda mati" jika tidak dibaca. Pada titik inilah Komunitas interpretasi bermain. Sejalan dengan potensi-potensi makna teks yang berubah dan berkembang, dengan mengutip pendapat Gadamer, El-Fadl menunjukkan bahwa komunitas interpretasi ini secara historis tidak mandiri, bersandar pada prasangka historis, selalu berubah dan berkembang. Atas dasar inilah El-Fadl dan Gadamer oleh pengkritiknya dikategorikan sebagai pengagum mazhab relativisme yang mendukung ketidakpastian makna. ${ }^{28}$ Dengan demikian manakala komunitas interpretasi ini membaca teks-dan itu akan dilakukan terus menerus karena para pembaca akan merujuk pada teks-akan didapatkan makna baru. ${ }^{29}$

Argumentasi di atas menunjukkan bahwa ada interaksi langsung antara teks dan komunitas interpretasi sehingga komunitas interpretasi menciptakan makna baru di satu sisi dan di sisi lain-Klaled meninjam teori James Boyd-teks menciptakan dan membentuk komunitasnya sendiri. El-Fadl menambahkan bahwa, saat dibaca, teks bukanlah penampung makna pasif, melainkan aktif terlibat dalam membentuk dan mengubah komunitas interpretasinya sendiri. ${ }^{30}$ Seperti diketahui, dalam historisnya, komunitas interpretasi ini juga sering berubah sehingga sangat beragam dalam menetukan makna dan terkadang

${ }^{28}$ Ibid., h. 123.

${ }^{29}$ Pada titik inilah Khaled menolak keras ototarianisme yang menghendaki teks mengandung makna yang telah ditentukan, stabil, tetap dan tidak berubah. Khaled M. Abou el Fadel, Ibid., h. 145146. Dan jika demikian maka pintu ijtihad sudah tertutup.

30Ibid., h. 123. 
saling tumpang tindih, terutama terkait tradisi linguistik, kultural dan metodologi yang berbeda karena dipengaruhi lingkungan sosial. Teks, jelas ElFadl, juga memiliki kemampuan untuk memainkan peran yang mengikat baik positif maupun negatif dalam proses evolusi perubahan komunitas interpretasi. ${ }^{31}$ Tampak keduanya bersitegang integritas dan kemandirian masingmasing. Dalam perspekti Islam, intgritas teks adalah memuat maksud tuhan, sementara integritas komunitas interpretasi merasa sebagai wakil Tuhan. ${ }^{32}$

Sebagai ilustrasi, hubungan keduanya mirip antara kartu perdana elektronik dan penggunanya. Kartu perdana sebenarnya memiliki potensi untuk komunikasi jarak jauh untuk siapapun dan di manapun, semetara pengguna juga berkeinginan sama, komunikasi jarak jauh kepada siapapun dan di manapun. Keduanya akan ketemu manakala ada aktivasi dari kartu itu, sehingga pengguna mengambil potensi yang dimiliki kartu itu. Yang menjadi problem adalah terkadang pengguna menginginkan komunikasi antar negara sementara kartu hanya bersifat lokal. Pada satu sisi pengguna juga bisa membuat komunitas antar negara sendiri, di sisi lain kartu juga bisa membentuk komunitas pengguna yang hanya bersifat lokal. Sehingga antara keduanya dibutuhkan kesamaan persepsi wilayah masing-masing agar ada titik temu. Hermeneutika El-Fadl dapat dilihat pada Gambar 2.

Dikarenakan talik ulur antar keduanya (teks dan komunitas), penetuan makna akan semakin kompleks sehingga menurut El-Fadl dibutuhkan "negosiasi" dan "konstruksi" guna menentukan makna. El-Fadl tidak menjelaskan kedua term ini secara eksplisit namun hanya memberi contoh kasus. Misalnya, negosiasi dalam dinamika tawar-menawar antar sebuah perintah dan wakil Tuhan yang melahirkan bentuk ketaatan. Ketaatan ini tidak dilakukan oleh Tuhan, itu dilakukan oleh teks dan pembaca. Dalam kasus ayat yang mengatakan "tidak ada paksaan agama dalam agama", oleh pembaca bisa jadi ini akan dimaknai seperti tidak boleh memaksa siapapun untuk masuk ilsam atau seseorang boleh dipaksa masuk Islam, tetapi tidak boleh memaksa untuk menyakini islam atau tidak boleh dipaksa melakukan salat, puasa dan berjilbab;

31 Khaled dalam hal ini juga menjelaskan bahwa dalam pemaknaan yang otoriter otonomi teks ini diambil alih dan mencegah evolusi perubahan komunitas ini dalam merespon perubahan sosial. Ibid., h. 125.

32 Ibid., h. 125. 
atau makna lainnya. Pada saat memunculkan pemaknaan-pemaknaan inilah pembaca sedang bernegosiasi dan mengkonstruksi makna teks. Mungkin, makna teks hanya bermaksud membahas salat, jilbab, murtad atau janji kesetiaan, sementara pembaca melakukan konstruksi sehingga menggiring pada pemaknaannya sendiri. Padahal teks selalu bersandar pada kata-kata yang tetap dan konsisten, sehingga seolah selalu bertentangan dengan kontuksi yang dilakukan pembaca. Semakin kuat menggiring teks maka akan semakin kuat teks menentangnya.

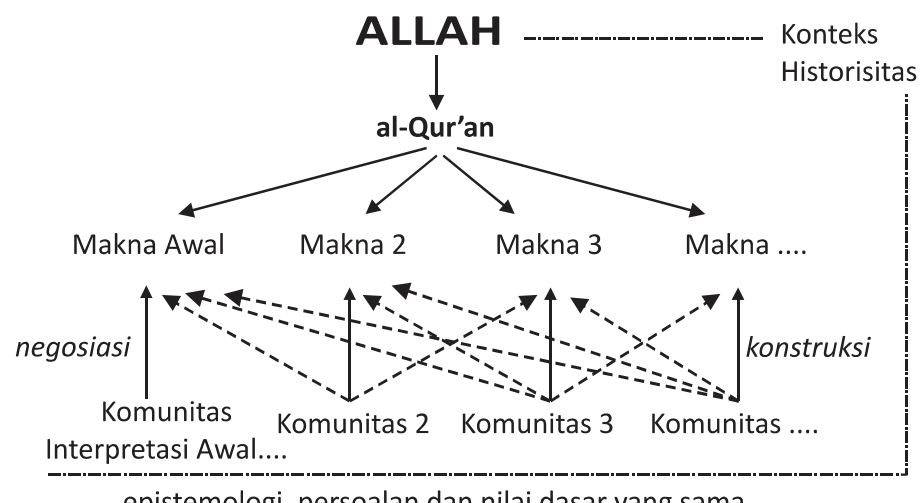

epistemologi, persoalan dan nilai dasar yang sama

\section{Keterangan: \\ $\longrightarrow$ : Hubungan langsung \\ -...... : Hubungan tidak langsung \\ . . _ _ _ : Potensi makna lain \\ Gambar 2. \\ Hermeneutika Khaled El- Fadl}

Ilustrasi di atas bukan menunjukkan bahwa pembaca melakukan kesalahan, melainkan ada kemungkinan pembaca berlebihan dalam memaknai teks yang melebihi batas rasional sehingga teks tidak akan melegitimasi kemampuan pembaca dalam pemaknaan. Jadi misalnya, ayat tadi dimaknai pembaca, "hukuman bagi pezina dan pemabuk tidak boleh dilakukan, karena sama dengan pemaksaan dalam beragama", maka penetapan makna seperti ini 
akan menggoyahkan legitimasi pembaca sehingga makna yang dihasilkan patut dipertanyakan. ${ }^{33}$

\section{E. Kontekstualisasi Hermeneutika El-Fadl dalam Hukum Islam: Syariah, Fikih, Ijtihad dan Mazhab}

Dalam konteks hukum islam, hermeneutika El-Fadl ini ini bisa ditarik sebagai penjelasan yang membedakan antara syariah dan fikih. Ini bisa dilihat dari gagasan mengenai potensi-potensi makna teks yang sangat terbuka untuk diambil salah satu atau beberapa makna tersebut oleh komunitas penafsir (baca: fuqahā'). Teks ini diistilahkan dengan syariah sementara salah-satu atau beberapa makna itu disebut dengan fikih. Syariah menurutnya adalah hukum tuhan yang bersifat abstrak dan ideal. Ini menunjukkan bahwa dalam syariah ada makna-makna yang dikehendaki Tuhan agar ditangkap oleh setiap generasi umat Islam. Artinya, di satu sisi Tuhan "sengaja" menyemayamkan maknamakna yang tak terbatas dalam teks al-Qur'an agar selalu sesuai dengan tuntutan zaman dan waktu. Sedangkan di sisi lain karena memiliki potensipotensi makna maka teks selalu bisa sebagai solusi di setiap zaman dan keadaan. Jadi keduanya bersifat dialogis. Sementara fikih adalah bentuk nyata manusia dalam memilih dan mengaplikasikan makna-makna yang dikehendaki Tuhan dalam syariat. Ada dua proses penting dari definisi ini. Pertama, memilih. Di suatu konteks tertentu, komunitas interpretasi memilih salah satu makna dari syariah karena dianggap sesuai dengan waktu dan keadaan mereka. Oleh mereka, satu makna ini disebut sebagai hukum, qaul, atau fatwa. Kedua, aplikasi. Ini merupakan kelanjutan dari proses pertama, setelah ada hukum, qaul atau fatwa ini, mereka kemudian mengaplikasikannya dalam wilayah praksis. Kedua proses inilah yang melahirkan fikih. Jadi syariah adalah makna-makna yang dihendaki Tuhan yang bersifat abstrak sementara fikih adalah satu makna dari makna-makna tersebut yang dipraktekkan satu komunitas tertentu. Dengan demikian, tujuan syariah adalah mewujudkan kemaslahatan bagi manusia sedangkan fikih adalah untuk memahami dan menerapkan syariah itu. ${ }^{34}$

Adanya perbedaan syariah dan fikih ini menunjukkan bahwa fikih baik berupa fatwa, qaul atau yang lain merupakan sesuatu yang tidak final karena sangat

33 Ibid., h. 131-132.

34 Ibid., h. 32. 
tergantung pada konteks dan hanya mewakili satu makna dari makna-makna yang disediakan Tuhan. Dan, yang final adalah potensi-potensi makna dalam syariah itu sendiri yang harus digali oleh komunitas interpretasi agar menghasilkan hukum-hukum baru yang responsif terhadap perkembangan zaman.

Komunitas interpretasi yang dicetuskan El-Fadl di atas secara sederhana bisa dimaknai sebagai komunitas keilmuan yang memiliki kesamaan epistemologi dan metodologi dalam menggali dan memilih makna-makna dalam teks (syariat) yang dalam tradisi fikih bisa disebut mazhab, mufti atau lainnya. Baginya, komunitas ini tidak hanya terbatas pada mazhab klasik seperti Maliki, Hanafi, Syafii dan Hambali. Komunitas yang kecilpun jika memiliki syarat maka bisa disebut sebagai mazhab (mufti, hakim dan lainnya) yang bisa mengeluarkan fatwa seperti MUI, Lembaga baḥth al-masāili NU dan tarjih Muhammadiyyah. Selain itu, El-Fadl tidak sepakat dengan upaya individu dalam menghadirkan satu makna. Menurutnya yang berhak mengambil satu atau beberapa makna adalah kumpulan para intelektual (fuqahā) yang otoritatif dengan minimal memiliki tiga syarat dan lima landasan sebagaimana di atas. Jadi otoritarianisme (pemaksaan satu hukum terhadap orang lain) menurutnya bisa merujuk pada tiga, yaitu 1) kelompok yang tidak memiliki syarat dan 2) individu baik yang memiliki syarat maupun tidak dan 3) kelompok yang memiliki syarat namun memaksakan kehendak mereka terhadap kelompok lain.

Namun demikian, El-Fadl tidak memberikan garansi bahwa komunitas fuqahä' yang memenuhi syarat tersebut selalu benar dan tepat dalam ijtihadnya. Atas dasar itu kemudian El-Fadl membuat dua kategorisasi mazhab fikih. Pertama, mazhab mukhattiiah, yaitu komunitas yang mempercayai bahwa akan selalu ada jawaban yang tepat dan benar, namun ini baru terungkap kelak di akhirat. ${ }^{35}$ Mazhab ini mengandaikan bahwa kebenaran hukum sudah ada sejak zaman azali. Hanya saja tidak banyak manusia yang mengetahui jawaban yang pasti mengenai suatu hukum. ${ }^{36}$ Maka tak heran jika ada sebagaian dari mereka yang benar dan sebagian yang lain salah. Karena, tambah mereka, jika jawaban sama-sama tepat maka dialektika dan perdebatan persoalan hukum menjadi nihil. Fungsi dari dialektika antar komunitas ini adalah agar selalu berusaha mendekati kebenaran itu yang kelak diputus oleh Allah. Dengan begitu tugas ko-

${ }^{35} \mathrm{Ibid}, 148$.

36Jazim Hamidi, Hermeneutika Hukum (Yogyakarta: UII Press, 2005), h. 75. 
munitas hanyalah berupaya menemukan makna hukum yang sesuai dengan masa dan kondisinya ketika berijtihad sementara kebenarannya diserahkan pada Tuhan.

Kedua, mazhab Mușawwibah, yaitu komunitas yang tidak mempercayai adanya jawaban yang benar dan tepat dari Tuhan agar ditemukan manusia. ${ }^{37}$ Alasan kelompok ini adalah, andai ada jawaban yang tepat dan pasti tentu Tuhan akan membuat teks yang Sărih dan tidak perlu penafsiran. Kebenaran dan ketepatan dalam hukum, tambah, kelompok ini bersifat "menggantung". Artinya, hukum itu benar atau salah tergantung dari perspektif, metodologi dan cara pembuktian dalam konteks tertentu. Namun demikian, mazhab ini percaya bahwa Tuhan tidak akan menyuruh untuk menemukan potensi-potensi makna itu manakala manusia tidak mampu. Jadi andaikan manusia itu berusaha tentu akan menemukan kebenaran itu, meski bersifat sementara atau hanya di dunia saja yang tergantung dengan konteks.

Dengan mengacu perkembangan keilmuan yang berkembang sangat pesat bahkan ribuan displin ilmu muncul di era kontemporer ini, maka konsep komunitas interpretasi (ijtihat jamí) menjadi suatu keniscayaan. Karena satu persolan hukum bisa dilihat dari belbagai perspektif keilmuan, sehingga produk hukum yang dihasilkan akan semakin mendekati kebenaran. Selain itu, adanya komunitas interpretasi ini menunjukkan bahwa dalam menggali makna itu juga ditemukan komunitas yang mengikuti (taqlīi). Tentu saja, taqlid di sini dimaknai secara positif, yaitu adanya kesadaran tentang kualitas dan kuantitas pribadi untuk mewakilkan segala urusan yang terkait dengan hukum Islam kepada para ahlinya (baca: komunitas ilmu hukum). Pengertian ini menunjukkan bahwa muqallid (pengikut) itu paham akan kompleksitas, cara dan orang memproduksi hukum islam sehingga tersadar akan kemamampuan dirinya yang tidak mendalami dan menyerahkanya kepada komunitas yang memiliki syarat-syarat tertentu.

\section{F. Hermeneutika Subjektif-Fiqhiyyah: Kritik dan Diferensiasi Pemikiran El-Fadl}

Kebiasaan dalam dunia akademik adalah kritik kontrukstif, salah satu alasanya adalah karena tidak akan ada suatu teori yang sempurna. Demikian

37Khaled M. Abou el Fadel, Speaking in God's Name, h. 148. 
pula El-Fadl dalam menelurkan teori ini tidak lepas dari kritik. Dalam mengkonstruksi dan mengkonsep teori hermeneutik El-Fadl tidak eksplisit sehingga pembaca tampak kesulitan mempelajarinya. Salah satu contoh adalah hermeneutik El-Fadl tampak lebih dekat dengan hermeneutik subjektif ala Gadammer ${ }^{38}$ namum dalam membahas pengarang, dalam hal ini Allah, El-Fadl "malu-malu" untuk mengatakan "matinya pengarang", sehingga mirip hermeneutika subjektif. Ini dibuktikan dengan pernyataan El-Fadl bahwa Tuhan hanyalah simbol yang bersifat emotif dalam tradisi hukum Islam dan dalam analisanya juga tidak terlalu banyak mengurai tentang peran Tuhan dalam teks. Dalam hal ini pola deduktif dalam epistemologi fikih klasik, al-Qur'an (baca: tuhan) sebagai sumber utama pengetahuan, masih "membayang-bayangi" ElFadl.

Bisa jadi hal di atas juga merupakan diferensiasi dari El-Fadl dengan hermeneutika Barat. Jika Barat meletakkan kematian pengarang dalam menafsirkan teks, maka El-Fadl, tidak mematikannya. Hanya saja, karena Tuhan tidak terjangkau rasionalitas, maka diwakilkan terhadap setting sosial-historis ketika teks diturunkan. Lebih dari itu, El-Fadl juga seolah ingin meletakkan teks dalam dua dimensi, yaitu sakral dan profan. Profan maksudnya teks bisa didekati dengan ilmu-ilmu sosial humaniora, karena merupakan produk budaya. Sakral artinya, meski produk budaya, teks langsung diturunkan oleh Tuhan.

Sejalan dengan kritik di atas, hermeneutik El-Fadl tampak inkonsistensi. Ini bisa dilihat dari penjelasan El-Fadl yang awalnya ingin mensinergikan segitiga hermeneutik, namun dalam praktisknya justru membatasi pada pergulatan antara teks dan pembaca (baca: komunitas interpretasi). Selain itu, konsep "pembaca" yang umum dipakai dalam teori hermeneutik diganti olehnya dengan konsep "komunitas interpretasi" yang mengandaikan adanya ketidakpercayaan El-Fadl terhadap kreatifitas dan kemampuan individu. Bisa jadi ini dipengaruhi latar belakangnya sebagai intelektual hukum atau fuqāh $\bar{a}^{\prime}$ yang dalam beberapa kasus kontemporer untuk menentukan suatu fatwa harus dilakukan bersama-sama (ijtihād jamî̀) oleh beberapa orang atau lembaga fatwa dengan syarat-syarat tertentu sehingga kurang menerima ijtihād fardī. Atau bisa

38 Yaitu usaha kritis, analitis dan kontekstual yang memposisikan teks pada masa sekarang yang terputus dari pengarang dan masa kelahiran teks. Lebih jelasnya baca, Kaelan, Filsafat Bahasa, Semiotika dan Hermeneutika (Yogyakarta: Paradigma, 2010), h. 268-272 dan 283-294. 
jadi konsep kualifikasi dan level mujtahid seperti mutlaq mustaqīl dalam tardisi usūl al-fiqh juga mempengaruhinya. Meski demikian, lagi-lagi, inilah sisi pembeda El-Fadl dengan hermeneutis islamis lain. Hermeneutika El-Fadl merupakan metodologi yang dipinjam dari barat, namun cara penggunaannya sudah dielaborasi dengan paradigma uṢül al-fiqh sehingga nuansa fikih masih sangat kental. Dengan kata lain, turāth yang berupa fiqh dan $u$ Șülnya olehnya tidak selalu diterjemahkan secara eksplist melainkan menyatu dalam kerangka berfikir.

Terakhir, ketika El-Fadl mengkritik otoritarianisme dan "menuduh" para pelakunya mengatasnamakan Tuhan, pada saat yang sama kritik yang dilakukannya juga mengatasnamakan Tuhan. Seolah El-Fadl juga ingin menjadi Tuhan baru. Bukankah "potensi pluralitas makna" juga mengharuskan mengakomodir "pluralitas potensi makna tunggal"? Mungkin orang akan memberi saran, alangkah lebih bijak manakala dalam menyikapi ini El-Fadl tidak membawa nama Tuhan, melainkan cukup berdasarkan logika pluralitas pemaknaan. Namun demikian, jika dianalisis lebih lanjut, maksud atas nama Tuhan yang dipakai El-Fadl ini ingin menunjukkan dan meluruskan bahwa sehebat apapun komunitas fuqah $\bar{a}^{\prime}$ hanya akan mewakili satu pendapat (maksud, makna) dari Tuhan. Karena itulah seorang hakim atau fuqahä' tidak boleh merasa putusannya yang paling benar sehingga bisa memaksa orang lain.

Karena deferensiasi di atas, tidak berlebih jika hermeneutika El-Fadl ini disebut dengan hermeneutika subjektif-fiqhiyyah. Disebut subjektif karena ElFadl meletakkan Tuhan atau pengarang sebagai titik tolak namun tidak melibatkannya secara langsung dalam pemilihan makna dan hanya berkontribusi terhadap makna awal. Sementara yang berperan dalam menentukan makna adalah teks dan komunitas interpretasi, serta Tuhan hanya diwakili keadaan sosial pada masa Nabi dan pada tahap selanjutnya ditinggalkan. Adapun dikatak fiqhiyyah karena objek dan epistemologi hermeneutika El-Fadl terintegrasi dengan tradisi fikih dan uṣūlnya.

\section{G. Kesimpulan}

Hermeneutika El-Fadl dilatarbelakangi kegelisahnya tentang adanya lembaga Fatwa yang cenderung mengandung unsur otoritarianisme. Keinginan untuk menghilangkan otoritarianisme inilah El-Fadl menawarkan hermeneutika subjektif yang berbasis pada interaksi antara teks dan komunitas interpretasi 
dan "sedikit peduli" terhadap peran pengarang, dalam hal ini Tuhan yang dijadikannya sebagai simbol syariah. Meski tidak ekplisit dalam menyusun teori hermeneutika, namun dengan analisa hermeneutis yang dalam, El-Fadl mampu menghadirkan pemaknaan ulang terhadap teks al-Qur'an-dan hadis-sekaligus menunjukkan potensi-potensi makna yang harus segera digali oleh umat Muslim, khususnya para pemberi fatwa. Ini terutama untuk menghindari pemaksaan agar hanya "beriman" pada makna tunggal sebagaimana kegelisah intelektualnya.

Lebih jauh, hermeneutika El-Fadl ini bersifat orisinil sehingga berbeda dengan hermeneutika intelektual Muslim kontemporer lain atau filusuf barat. Buktinya adalah El-Fadl tidak mengakui kemampuan individu dalam menafsirkan teks, melainkan "komunitas" atau dalam bahasa fikih disebut mujtahid jam'i dan mampu menjelaskan posisi Tuhan dalam tahapan menafsirkan teks tanpa harus menghilangkannya sebagaimana hermeneutika subjektif dari Barat. Selain itu keunikan dari El-Fadl adalah meletakkan ilmu-ilmu tradisi penafsiran klasik sebagai langkah awal menemukan makna, kemudian beralih kepada teori-teori sosial-humaniora terutama filsafat bahasa dan sosiologi.

Tulisan ini-mungkin-banyak kekurangan dikarena pembacaan parsial tentang El-Fadl yang bisa jadi justru baru mewakili setengah pemikirannya atau bahkan bertolak belakang dengannya. Ini dikarenakan sumber primer yang dipakai dalam tulisan ini didominasi buku Speaking in God's Name: Islamic Law, Authority and Woman dan sedikit merujuk buku-bukunya yang lain serta itu dimungkinkan dalam interpretasi itu sendiri. Namun demikian dibanding artikel-artikel lain yang sudah membahasnya tampak ada sisi pembeda. Salah satunya, tulisan ini menunjukkan bahwa yang digunakan El-Fadl adalah hermeneutika subjektif-fiqhiyyah yang berangkat dari otoriterisme.]

\section{DAFTAR PUSTAKA}

Abdullah, Amin, Pendekatan Hermeneutik dalam Studi Fatwa-fatwa Keagamaan. dalam pengantar buku Khaled M. Abou el-Fadel, Atas Nama Tuhan: Dari Fiqh Otoriter ke Fiqih Otoritatif. terj. Cecep Lukman Yasin, Jakarta: Serambi Ilmu Semesta, 2004. 
Auda, Jasser, Maqasid al-Shariah as Philosophy of Islamic Law: A System Approach, London: The International Institute of Islamic Thought, 2007.

el-Fadel, Khaled M. Abou, Melawan Tentara Tuhan, Jakarata: Serambil Ilmu Semesta, 2003.

L Speaking in God's Name: Islamic Law, Authority and Woman. Oxoford: Oneworld Publications, 2003.

Friedman, R. B., "On the Concept of Authority in Political Philosophy." dalam Joseph Raz ed.. Authority. Oxford: Basil Blackwell, 1990.

Hamidi, Jazim, Hermeneutika Hukum. Yogyakarta: UII Press. 2005.

Kaelan, Filsafat Bahasa, Semiotika dan Hermeneutika, Yogyakarta: Paradigma, 2010.

Machasin, "Sumbangan Hermeneutik terhadap Ilmu Tafsir" Gerbang: Jurnal Studi Agama dan Demokrasi, Vol. 14. No.V, Surabaya: eLSAD, 2003.

Misrawi, Zuhairi, "Khaled Abou El-Fadl Melawan atas Nama Tuhan," dalam PerspektifProgresif, Edisi Perdana Juli-Agustus, 2005.

Schacht, Joseph, "Theology and Law in Islam," dalam G.E. von Grunebaum (ed.), Theology and Law in Islam, Weisbaden: Otto Harrasowitz, 1969.

Sumaryono, E., Hermeneutik: Sebuah Metode Filsafat, Yogyakarta: Kanisius, 1999.

Yusriandi, Hermeneutika Hadis Abou El-Fadl, dalam Sahiron Syamsuddin (ed). Hermeneutika al-Qur'an dan Hadis, Yogyakarta: elSAQ Press, 2010. 
